\title{
Differentiation of Students in the Early Danish Welfare State: Professional Entanglements Between Educational Psychologists and Psychiatrists
}

\author{
Christian Ydesen, Bjørn Hamre \& Karen E. Andreasen
}

\begin{abstract}
Historically, numerous contextual factors have influenced the practice of differentiating students. Scholars and practitioners consider it a context-sensitive practice subject to negotiations and entanglements among various agents, groups, interests, ideas, and values. Drawing on Foucault, this article pursues the practices, negotiations, and entanglements surrounding differentiation processes and IQ testing's use in the early Danish welfare state. We argue that the differentiating practice of IQ testing in the Danish educational system resulted from various factors, including the increasing professionalisation of the educational system. This practice entailed an increased division of labour among professional groups; debates reflecting differing ideas about eugenics, heredity, and social equality; the schooling of psychologists and psychiatrists in Denmark; and the development of psychology and psychiatry as academic disciplines. In that sense, we will demonstrate that changes in society's understanding of intelligence incorporating a greater use of environmental explanations can be said to reflect the emerging welfare society's security mechanisms, and a willingness to cope with and address social inequality in an evolving and supposedly universalistic Danish welfare state.
\end{abstract}

Keywords $\bullet$ Intelligence testing, welfare state, professions, Denmark, Foucault

\section{Introduction: Differentiation, IQ testing, and the Danish welfare state}

It made me think that what we measured in fact was just what we decided at some meetings. ${ }^{1}$

The opening quotation is from a 1979 interview conducted with the acclaimed Danish educational psychologist Thomas Sigsgaard (1909-1997) concerning publication of his 1943 revision of the Binet-Simon intelligence test. During that interview, Sigsgaard expressed his disappointment over how his revision failed to spark reaction from his peers, even though it acknowledged the greater role environmental factors played in measuring intelligence than had been brought out in the previous

1 Kaj Spelling, "Skolepsykologerne og deres prøver," in Børn, loerere, psykologer: En bog til Thomas Sigsgaard, ed. Jesper Florander and Hans Vejleskov (Copenhagen: Munksgaard, 1979), 103 (our translation).

Christian Ydesen is Associate Professor of Educational Science at the Department of Learning and Philosophy, Aalborg University, Denmark.

Email: cy@learning.aau.dk

Bjørn Hamre is Associate Professor of Educational Science at the Department of Media, Cognition, and Communication, University of Copenhagen, Denmark.

Email:hamre@hum.ku.dk

Karen E. Andreasen is Associate Professor of Educational Science at the Department of Learning and Philosophy, Aalborg University, Denmark.

Email: karena@learning.aau.dk 
1930 version. ${ }^{2}$ It should be noted that, as an author, Sigsgaard may have been unduly motivated in terms of emphasising his own positive contributions, as well as for highlighting his own role and the importance of the changes he made to the Danish standardisation of the Binet-Simon test in 1943. Even so, it remains beyond a doubt that intelligence quotient (IQ) testing in general and the concept of intelligence in particular was a topic of considerable debate in Denmark during the era.

The period between the 1930s and the 1960s represents the formative age of the Danish welfare state. ${ }^{3}$ The Nordic model, also known as the universalist model, builds on the idea of citizenship, which implies a state responsibility to offer, distribute, and re-distribute a variety of state-financed social services-education, medical assistance, and so forth - which will accrue as social benefits to its citizens. ${ }^{4}$ During this formative period, the institutions charged with providing such services were themselves also evolving. The government's capacity to offer these services also meant the emergence of new professions to represent the state in this capacity. Serving in this role of state representatives, a cadre of certified professionals would develop the tools and practices by which they could manage the diversity among citizens, and make decisions concerning how best to distribute and administer public goods among the people.

To this development, we can add that education was considered both a public good and a citizen's right, but was also meant to serve as a cornerstone of both the welfare state and the labour market. ${ }^{5}$ This ability to educate the citizenry emphasised the importance of mobilising the so-called "intelligence pool" — that is, the available human resources - in the population. It also meant such "correct" or suitable educational opportunities would be offered to those individuals deemed to be the "right" sort, meaning select members of the populace, and those offering these opportunities would need to employ technologies to allow them to differentiate among students in a steadily growing educational system. In the fields of education and health, IQ testing's use as a newly salient technology became a key tool in professionals' decision-making processes. ${ }^{6}$ By coming to play such a critical role, IQ testing also grew to represent a field of tension among professional groups (teachers, psychologists, and psychiatrists) and various stakeholders. On the one hand, this tension concerned who was best qualified to perform the testing (teachers, psychologists, or physicians) and, on the other hand, it addressed the idea of even performing IQ testing at all. Drawing on Foucault, ${ }^{7}$ the right to administer the IQ testing came to

2 Christian Ydesen, The Rise of High-Stakes Educational Testing in Denmark, 1920-1970 (Frankfurt: Peter Lang Verlag, 2011).

3 Niels Ploug, Ingrid Henriksen, and Niels Kærgård, Den danske velfeerdsstats historie: Antologi (København: Socialforskningsinstituttet, 2004), 14; Mette Buchardt, Pirjo Markkola, and Heli Valtonen, "Education and the Making of the Nordic Welfare States," in Education, State, and Citizenship: A Perspective in the Nordic Welfare State History, ed. Mette Buchardt, Pirjo Markkola, and Heli Valtonen (Helsinki: NordWel Studies in Historical Welfare State Research, 2013).

4 Gøsta Esping-Andersen, The Three Worlds of Welfare Capitalism (Princeton: Princeton University Press, 1990).

5 Ning de Coninck-Smith, Charlotte Appel, Morten Fink-Jensen, Christian Larsen, Erik Nørr, Pernille Sonne, Anette Faye Jacobsen, Christian Ydesen, and Lisa Rosén Rasmussen, eds., Dansk skolehistorie: Hverdag, vilkår og visioner gennem 500 år, Volume IV (Aarhus: Aarhus universitetsforlag, 2013).

6 Ydesen (2011).

7 Michel Foucault, "The Confession of the Flesh," in Power/Knowledge: Selected Interviews and Other Writings (1972-1977), ed. Colin Gordon (London and New York: Pantheon Books, 1980), 194-228. 
be used as a strategic pawn in the legitimisation of educational psychology as a profession.

Hovering over these fields of tension-and ultimately authorising professionals' work on the ground - was the emerging universalist welfare state itself, whose members brought to bear their own political ambitions and educational plans. Within these layers of what might be termed "the state anatomy," struggles arose about who (which agencies) would be authorised to assess intelligence, how they could pursue this assessment, and for what purposes the final product would be used. Sigsgaard appears to be stating that neither the concept of IQ nor the practices of assessing it were anything more than a negotiated outcome among professionals who represented the competing interests and contexts in which IQ testing was applied.

The process of developing criteria to use in differentiating among students in the school setting has thus been subject to numerous contextual factors. Scholars and practitioners consider it a contextsensitive practice, influenced by and subject to negotiations and entanglements among various agents, groups, interests, ideas, and values. In this article, we pursue these practices, negotiations, and entanglements surrounding differentiation and the use of IQ testing in the early Danish welfare state. Sigsgaard's reflections during the interview offer a preview of such processes and the frustrations that accompanied them. The early Danish welfare state represents a time of social upheaval marked by IQ testing's introduction into the Danish school system. In that same period, important developments in the fields of psychology and psychiatry occurred in Denmark, and competing ideas about such disparate forces as governmental forms, eugenics, heredity, and social equality sparked controversy among stakeholders both within the educational community and throughout the wider society. Seeking tools to improve the process of differentiating among individuals and how to treat diversity, those holding authority promoted and expressed their belief in IQ testing's merits. As we have argued above, two important elements influenced the use of IQ testing — the interests of the emerging welfare state and tensions among professionals - and the process was seemingly highly sensitive to contextual factors. Following these assumptions, we ask the following research question: How can we understand the background, development, and influence of student differentiation occurring as a result of the relations among IQ testing, the defining professionals, and the welfare state?

In analysing and interpreting these processes, we draw on insights from Michel Foucault's writings on power and governance, ${ }^{8}$ and the understanding of the psy-disciplines as fleshed out by Nikolas Rose. ${ }^{9}$ Fields such as psychology and psychiatry thus are seen as representing different regimes of truth and playing different roles in the forming of the state. In his analysis of the British educational system, Stephen J. Ball draws on Foucault's technologies of discipline and security. ${ }^{10}$ Whereas schooling systems in states practice norming and forming of pupils (through mechanisms of discipline), they also practice the treating of diversity through technologies of differentiation (mechanisms of security). Fields such as psychology, psychiatry, and education play distinct roles in treating the relation between the mechanism of dis-

8 Foucault (1980); Michel Foucault, Security, Territory, Population: Lectures at the Collège de France, 1977-78 (New York: Palgrave Macmillan, 2009).

9 Nikolas Rose, Inventing Our Selves: Psychology, Power, and Personhood (Cambridge: Cambridge University Press, 1998).

10 Stephen J. Ball, Foucault, Power, and Education (New York: Routledge, 2013). 
cipline and that of security. In our conclusion, we frame the findings of our analysis by referring to this theoretical positioning.

\section{Sharpening the focus: A historiographical view}

In the late nineteenth century, psychologists such as William Stern and Francis Galton, along with several others, were researching different conceptualisations of the phenomenon of "intelligence." In addition, they were studying various means of measuring intelligence, and the relevant disputes concerning the feasibility of such assessment were already recognised at that time. In 1904, Alfred Binet was invited to join a French ministerial commission appointed to design a test for selecting pupils needing special education. ${ }^{11}$ His renowned design of the seminal IQ test for this purpose spread across the world in revised versions, ${ }^{12}$ and its application played a key role in numerous educational practices; Denmark was no exception.

Ever since its introduction, IQ testing has been a research object across many academic disciplines: psychology, history, and sociology to list but a few. Much of the historical research done on IQ testing, however, has focussed on tracing the roots and development of the test itself, and to some extent, the practices of which such testing has been a part and how the test has contributed to their formation. ${ }^{13}$ The historiography clearly shows that test practices have been and continue to be widespread, with their use playing a critical role in shaping a great variety of social contexts throughout societies in general and among professionals in particular.

Historian Annette Mülberger has considered the need for contextual factors in the study of the history of mental testing. ${ }^{14}$ Contemporary historiography has often been concerned with such themes as conceptualisations of intelligence and the nature-nurture perspective. However, because the differentiation processes associated with IQ testing are so contextualised, ${ }^{15}$ we want to pick up the baton of the earlier research and offer in-depth contextual insights drawn from the Danish case in terms of the roles played by and interactions between psychologists and psychiatrists. ${ }^{16}$

11 John Carson, "Mental Testing in the Early Twentieth Century: Internationalizing the Mental Testing Story," History of Psychology 17, no. 3 (2014), 251.

12 Ibid.

13 See, e.g., Kirk A. Becker, "History of the Stanford-Binet Intelligence Scales: Content and Psychometrics," in StanfordBinet Intelligence Scales (5th ed.), Assessment Service Bulletin, no. 1 (2003); John Carson, The Measure of Merit: Talents, Intelligence, and Inequality in the French and American Republics (Princeton: Princeton University, 2007); Paul D. Chapman, Schools as Sorters: Lewis M. Terman, Applied Psychology, and the Intelligence Testing Movement, 1890-1930 (New York and London: New York University Press, 1988); William J. Reese, Testing Wars in the Public Schools: A Forgotten History (Cambridge: Harvard University Press, 2013).

14 Annette Mülberger, “The Need for Contextual Approaches to the History of Mental Testing," History of Psychology 17, no. 3 (2014), 177-86.

15 See, e.g., Franz Samelson, “On the Science and Politics of the IQ," Social Research 42 (1975), 467-88.

16 The topic of IQ testing has been thoroughly researched in countries such as Brazil, France, the Netherlands, the former Soviet Union, Sweden, the United States, and the United Kingdom, e.g., Thom Axelsson, Rätt elev $i$ rätt klass: skola, begåvning och styrning, 1910-1950 (Linköping: Linköpings universitet, 2007); Nelleke Bakker, "A Culture of Knowledge Production: Testing and Observation of Dutch Children with Learning and Behavioural Problems (1949-1985)," Paedagogica Historica 53, nos. 1-2 (2017), 7-23; Carson (2007); Christopher F. Goodey, A History of Intelligence and "Intellectual Disability:" The Shaping of Psychology in Early Modern Europe (Farnham, Surrey and Burlington: Ashgate, 2011); Leslie S. Hearnshaw, The Shaping of Modern Psychology (London and New York: Routledge \& Kegan Paul, 1987); Ana Maria Jacó-Vilela, "Psychological Measurement 
In Danish historiography, the record shows several examples (some would note a distinct tendency) of professional groups having written their own histories, including that pertaining to IQ testing. ${ }^{17}$ Exceptions to this practice are historical works on the transnational nature of Danish IQ testing, and its origins, developments, and translations into practice. ${ }^{18}$ In general, the contextual perspective, and the links between IQ testing and the emerging Danish welfare state across both the inter-war years and the early post-war years, would benefit from further exploration, as mentioned. Thus, in this article, we will explore certain contextual factors, along with their role and implications in terms of differentiation and IQ testing in the early Danish welfare state. Denmark constitutes an interesting case study because the period from the 1930s to the 1960s was formative for the much-commended modern Nordic welfare model as typologised by Gøsta Esping-Andersen. ${ }^{19}$ The Nordic welfare model is, among other things, characterised by extending universal tax-financed welfare to citizens in an attempt to encompass and care for a given country's entire population. Therefore, determining how professionals affiliated with the Danish welfare state treated diversity within the populace, including which tools, technologies, and measures they invoked to treat a disparate, potentially problematic population, is of particular interest to our research. ${ }^{20}$

\section{IQ testing and the educational field}

Understanding the workings of a particular welfare state regime makes the field of education particularly relevant. In a certain sense, we may view education as the frontline pillar and vanguard of the state and societal order. The educational system plays a key role in differentiating among, and in producing and reproducing, structures of society. ${ }^{21}$ It is the locus wherein the majority of children and families most actively experience their first encounter with the state and societal order in the guise of state-sanctioned professionals, practices, technologies, and knowledge. Simultaneously, the field of education is a contested one, replete with numerous stakeholders holding assorted interests, different professional groups subscribing to competing knowledge paradigms, and various ideas concerning practice.

As argued above, a sub-field of particular interest is IQ testing because it repre-

in Brazil in the 1920s and 1930s," History of Psychology 17, no. 3 (2014), 237-48; Irina Leopoldoff,

"A Psychology for Pedagogy: Intelligence Testing in the USSR in the 1920s," History of Psychology 17, no. 3 (2014), 187-205; Steve McNutt, "A Dangerous Man: Lewis Terman and George Stoddard, Their Debates on Intelligence Testing, and the Legacy of the Iowa Child Welfare Research Station," Annals of Iowa 72 (2013), 1-30; Sandy Sufian, "Compounded Anxieties: Adoptive Family Building and the Role of Disability in Adoption IQ Studies," Journal of the History of Childhood and Youth 7 , no. 3 (2014), 398-429.

17 See, e.g., Carsten Bendixen, Psykologiske teorier om intelligens og folkeskolens elevdifferentiering: En analyse af transformationen af psykologiske teorier om intelligens som baggrund for skole-psykologiske og poedagogiske afgørelser vedrørende elevdifferentiering i det 20. århundredes folkeskole (Roskilde: Forskerskolen i Livslang Læring, Roskilde Universitetscenter, 2006).

18 Bjørn Hamre, Potentialitet og optimering i skolen, problemforståelser og forskelsseetninger af elever (Copenhagen: Aarhus University, 2012); Bjørn Hamre and Christian Ydesen, "The Ascent of Educational Psychology in Denmark in the Interwar Years," Nordic Journal of Educational History 1, no. 2 (2014), 87-111; Ydesen (2011).

19 Esping-Andersen (1990).

20 Cf. Ball (2013).

21 Buchardt, Markkola, and Valtonen (2013). 
sents a field of tension among the state, pedagogues, teachers, psychologists, and psychiatrists, not to mention pupils and parents. Since 1930, when intelligence testing was first formally introduced into the Danish public school system, such testing had gradually come to function as the key tool employed for a streaming practice that determined which children would be allowed to remain in the "normal school" (normalskolen) and which should be transferred to "remedial education" (vorneskolen). ${ }^{22}$ Therefore, any change in IQ testing procedures would have resulted in a massive impact on this streaming practice in general and on the children tested in particular. In other words, IQ testing was well on its way to becoming a key social service promulgated by the emerging welfare state, allowing it to maintain its prerogative of defining normalcy and deviance, and thus this governmental body could also exert significant influence over life trajectories and determine which early professional interventions would be appropriate to apply to children in the school setting.

To examine the contextual conditions of Danish IQ testing between 1930 and 1960, we have selected three empirical focus areas and structured this article accordingly. The first section draws a broad picture of the public debates concerning IQ testing. We seek to gain an understanding concerning competing views, discourses, and ideas about intelligence coming to the fore in the sometimes heated debates on the status of individuals labelled "feebleminded." We will also explore how these debates were often rooted in the state's political directions. The second section zooms in on the Danish educational psychologists' contextual situation during the period. Educational psychology was a new profession seeking to gain a foothold, and the profession often found itself in a precarious state. The struggles surrounding this emerging profession are thus pivotal to understanding IQ testing as practiced in Denmark. The third section further narrows our focus to the entanglements between child psychiatry and educational psychology. Much as educational psychology was working to ground itself as a critical and useful discipline, child psychiatry was also in the process of establishing itself as a professional field. Therefore, the links and connections between educational psychology and child psychiatry are relevant to explore because the negotiations between practitioners in these nascent professions were particularly determinate for differentiating among students in the early Danish welfare state in general and the development of IQ testing in particular. These three analyses-constituting a funnel-like zooming analytical movement-represent related perspectives on the analytical focus of this article: the relations among differentiation, IQ testing, the defining professionals, and the welfare state. Our conclusion will link the findings from the three analyses to draw a more generalised picture. In doing so, the final discussion will add to our knowledge about how the state is actually crafted via educational practices such as differentiation and the configurations between professional groups. In this concluding section, we incorporate Stephen Ball's analysis of the educational system to discuss both educational psychology's and psychiatry's roles in how the state approaches and treats societal diversity. The materials and sources applied in the three analyses include contemporary publications by some of the leading and trendsetting agents within the fields of psychology and education whose work was published in Nordic educational journals as well

22 Ydesen (2011). 
as state-of-the-art research drawing on primary sources from the Copenhagen and Frederiksberg City Archives.

\section{Public debates on IQ testing: From nature to nurture}

The concept of intelligence as an innate, fixed condition is especially visible in the way in which the emerging Danish welfare state dealt with eugenics and the question of how to handle "feeblemindedness" occurring in the population. The example of those believed to be feebleminded underscores intelligence testing's importance as a tool that could be exploited to use in sorting those deemed unfit for society from those whose inclusion was considered beneficial and therefore appropriate. During the 1930s, public debates in Denmark concerning how to measure intelligence were closely related to questions regarding the status of the "feebleminded" in society. ${ }^{23}$ As we will present in this section, IQ testing was viewed as an important legitimisation for sorting the population. This attitude is clearly reflected in two Danish journals of the day, Folkeskolen (The Public School) and Børnesagens Tidende (Journal of Childcare). Between 1930 and 1945, Folkeskolen featured many debates about schooling, psychology, and the increasingly critical roles played by both intelligence testing and the psychologist in the educational setting. A recurring angle asked how sorting schoolchildren would confer the greatest benefit to society. Børnesagens Tidende, published since 1906, was connected to Dansk Børneforsorg (the Danish Childcare Association). This journal published debates on the conditions of those children regarded as problematic, and its articles discussed the claim that children's issues were society's responsibility, a perspective reflecting the welfare state's rise. Among the issues debated was the relationship between nature and nurture to gain an understanding of children whose behaviour was deemed problematic.

These debates reflected some of the Danish legislative initiatives concerned with heredity in the population. As was the case in many other European countries during this period, a political will existed in Denmark towards practicing eugenics. Its goal was to prevent groups regarded as genetically inferior from reproducing. This will was reflected in political and public debates of the inter-war years in which the quality of the population was discussed. ${ }^{24}$ During the 1920 s, politicians and scientists occupied with eugenics established an alliance. In 1920, Danish Minister for Social Affairs Karl Kristian Steincke (1880-1963) designated a political program for practicing eugenics, inspired by similar views under discussion in the United States. ${ }^{25}$ These views were regarded as necessary in preparing for the future welfare state, which would feature an association between social policy and eugenics. During the 1920s and 1930s, a body of legislation was approved in the Danish Parliament by both right- and left-wing parties. These eugenicist views gained acceptance among disparate societal groups, whose members appeared supportive of the state's interference in the population's reproductive rights. ${ }^{26}$ Numerous laws were passed during

23 Some of the following passages covering the public debate on feeblemindedness are paraphrases from Hamre's PhD dissertation, Hamre (2012), 118-23. The passages have been recontextualised to accord with the framing of this article's subject.

24 Lene Koch, Racehygiejne i Danmark, 1920-1956 (Copenhagen: Gyldendal, 2000), 25.

25 Ibid., 40.

26 Ibid., 51. 
those years, for example, the Detention Act of 1925 (interneringsloven), the Welfare Act of 1933 (forsorgsloven), and the Feebleminded Act of 1934 (andssvageloven), all of which linked eugenicist arguments with socio-political efforts to safeguard society against crime and the unrestrained multiplication of the "feebleminded." 27 Such efforts were important in supporting schools' preoccupation with separating, as early as possible, pupils who could be assessed as "feebleminded." The Welfare Act of 1933 instructed municipal social committees to file reports on children who could not follow normal teaching, ${ }^{28}$ which would allow for transferring them to institutions designated for the "feebleminded." ${ }^{29}$

Even before the passage of any specific act concerning special education in Denmark, however, legislative measures had been instituted that focussed on pupils considered feebleminded. This desire to sort and separate pupils was later confirmed by a 1943 legislative initiative: "Children who are assessed [as] feebleminded should not be in the remedial education classes of the public school." ${ }^{30}$ This ambition to exclude certain groups of pupils was influenced and extended by eugenicist concerns. Exclusion was the term used for this type of sorting, an activity that was justified and legitimised in terms of societal needs.

Debates published in Folkeskolen and Børnesagens Tidende reflected worries over how the future population in Denmark might develop. One example is depicted in the general apprehension expressed about a declining birth rate, leading to fears that the "less-intellectually gifted" segment of the population would realise an increase in its share. Themes such as societal degeneration led to a specific discussion on the importance of separating the "feebleminded" from the rest of the population as soon and as quickly as possible. Some chroniclers discussed the need to defeat "feeblemindedness," which, in the debate, was positioned as a threat to the family and the future of Danish society. During the late 1800s and up to the 1950s, this idea of the "feebleminded" increasingly was cast as describing individuals considered "defective and dangerous." This depiction reflected a distinct change, compared with the image of earlier times in which those thought to be feeble of mind had been viewed as wretched souls needing society's care and attention. ${ }^{31}$ Thus, this type of anxiety in the debates led to discussions on how to discover and address "feeblemindedness" before it was too late to render assistance. While the idea of prevention was not explicitly articulated in the school debates, it can be understood as a dispositive ${ }^{32}$ that regulated concerns running through the discussions of the period.

An article entitled "The Defeat of a Race?" appeared in Folkeskolen. In it, the chronicler expressed anxiety over a declining birth rate and posited whether this

27 Birgit Kirkebæk, Abnormbegrebet i Danmark i 20'erne og 30'erne med sarlig henblik på eugeniske bestrcebelser - og iscer i forhold til åndssvage (Copenhagen: Danmarks Lærerhøjskole, 1985).

28 The mainstream schools were often regarded as normal schools. The term normal teaching refers to the teaching model or norm prevailing in the mainstream schools at that time, compared with methods that may have been applied in the remedial schools.

29 Kaj Ingbøl, “Den rettidige forsorg for lettere aandssvage,” Folkeskolen (1937), 188.

30 Folkeskolen (1943), 525.

31 Birgit Kirkebæk, Da de åndssvage blev farlige (Holte: SOCPOL, 1993); Birgit Kirkebæk, Uduelig og ubrugelig: Andssvageanstalten Karens Minde, 1880-1987 (Holte: SOCPOL, 2007).

32 Foucault (1980), 194-228. 
was one of the many examples of degeneration occurring in the "Danish race." ${ }^{33}$ The 1935 founding of the government's Population Commission sought to devise political strategies to address the perceived problem of a declining population and, thus, was an expression of social engineering designed to develop new policies for family planning in Denmark. ${ }^{34}$

By the 1940s, psychologists increasingly recognised the need to consider numerous factors along with intelligence when transferring a child to the remedial education setting. ${ }^{35}$ IQ testing's ability to generate useful pedagogical data came under fire, resulting from a rising number of children transferred to remedial classes. In 1948, Scandinavia's first educational psychologist Henning Meyer wrote: “The numerical results of intelligence measuring expressed in intelligence age and intelligence quotient are in themselves of limited interest. They only receive value when compared with other information about the child, information about social, family, physical, and mental conditions." ${ }^{36}$ Moreover, by 1951, this emphasis on environmental factors was also evident in the syllabus of the training program for educational psychologists at the University of Copenhagen in which the role of the environment in intelligence testing was clearly reflected. ${ }^{37}$

After the end of the German occupation of Denmark in 1945, educational psychologists increasingly acknowledged that even the new 1943 standardisation of the Binet-Simon intelligence test was rapidly becoming obsolete. The concept of intelligence as something innate and fixed was being challenged by new beliefs stipulating that intelligence development instead was dynamic and subject to environmental factors. ${ }^{38}$ This field of tension among competing concepts of intelligence was expressed in the thoughtful reflection of the prominent Danish educational psychologist Sofie Rifbjerg:

Ordinarily, children who have grown up under normal and steady conditions will retain roughly the same IQ throughout their lives, but there are so many children who do not grow up under such conditions or who at some point in their lives have experienced shock or impeding factors that one, as an educator, should be cautious in accepting that the way a child appears must be and always will be the way the child remains. ${ }^{39}$

This contradictory duality concerning the nature of intelligence flourished among Danish post-war educational psychologists. On the one hand, the inter-war IQ range of remedial schoolchildren, set at 70-90, was increasingly considered vague and non-categorical. Despite the duality, this ambiguity failed to result in any substantial

33 J. Troldahl, “En Race gaar under?” Folkeskolen (1933), 803.

34 Cecilie F. Banke, Den sociale ingeniørkunst i Danmark: Familie, stat og politik fra 1900 til 1945 (Roskilde: Roskilde Universitetscenter, 1999).

35 Frederik Christian Kaalund-Jørgensen, "Hvad gør vi for de Børn, der ikke kan følge Folkeskolens almindelige Undervisning?” Hjälpskolan (1942), $90 \mathrm{f}$.

36 Henning Meyer, "Psykologien og Skolen," in Opdragelse og undervisning i Danmark (Vol. I), ed. E. Torsting (Copenhagen, 1948), 287-307, 303.

37 Ydesen (2011), 121.

38 Ibid., 122.

39 Sofie Rifbjerg, Hjoelpeskolebørn (2d ed.) (Copenhagen: Gyldendals Pædagogiske Bibliotek, 1963), $238 \mathrm{f}$. 
impact on the widespread practice of IQ testing. Such tests continued to be extensively employed in Denmark, as reported in 1948 to the United Nations Educational, Scientific, and Cultural Organisation. ${ }^{40}$

In October 1945, the government formed a commission under the leadership of Professor Hal Koch (1904-1963) tasked with addressing the special problems and needs of youth. ${ }^{41}$ Until 1952, this commission drafted no fewer than 26 reports on aspects pertaining to youth and society. One area of focus was the mustering of the intelligence pool. The commission had estimated that from 10 per cent to 20 per cent of a birth cohort possessed an IQ greater than 115, an assessment regarded as a prerequisite for completing higher secondary-level education. ${ }^{42}$ In the 1940 s, because less than 5 per cent of a birth cohort was completing higher secondary education (Alevels), a political solution was brokered to remedy this gap. An important factor behind this demand was the political connection established between higher education and economic growth. Rising educational achievement was viewed as a prerequisite for the country's continued economic success. Even so, criticism of IQ testing continued into the 1950s, with Danish educational psychologists coming to its defence. In the writings of educational psychologist Ingvard Skov-Jørgensen from Horsens, we find one such example:

It is not an uncommon perception that an educational psychology examination consists of [nothing more than] a Binet intelligence test. That is a very primitive perception. An educational psychology examination means that the results of different tests are compared with the many different pieces of information from different sources and the psychologist's own observations. The work of educational psychology consists in connecting these fragments like the parts of a mosaic window [to create] a picture of the child's situation. ${ }^{43}$

In 1955, Ejvind Jensen and Wilhelm Marckmann of the Emdrupborg experimental school, in which a comprehensive testing battery was used that included an intelligence test called the Uppsala school readiness test, also argued the test should not be judged to be a completely objective instrument of measurement. It was only a tool used to advise and to guide professional assessment. ${ }^{44}$

Criticism intensified. In 1966, Marckmann found it necessary to refer to a passage in the Emdrupborg six-year report, which noted that the Uppsala school readiness test was never meant to stand alone in evaluating a child's intelligence. ${ }^{45}$ The infrequent use of the term "IQ" is also noteworthy in this report, demonstrating a markedly humbler approach to the certainty of the IQ test and its result. Instead,

40 UNESCO, School Psychologists, Vol. 105 (Geneva: UNESCO, 1948), $57 \mathrm{f}$.

41 The remaining passages in this section are paraphrases from Ydesen's $\mathrm{PhD}$ dissertation, Ydesen (2011), 117-18; 142-43. They have been recontextualised and updated in light of this article's focus.

42 Ida Juul, “Den danske velfærdsstat og uddannelsespolitikken,” Uddannelseshistorie 40 (2006), 74.

43 Ingvard Skov Jørgensen, Det skolepsykologiske arbejde i Danmark (Copenhagen: Skolepsykologisk forlag, 1955), 4.

44 Ejvind Jensen and Wilhelm Marckmann, “En prøve for skolebegyndere," Dansk Podagogisk Tidsskrift 3 (1955), 168.

45 Wilhelm Marckmann, "Nogle erfaringer fra brug af Uppsalaprøven," Dansk Podagogisk Tidsskrift 14 (1966), 316. 
Marckmann often used the term "Binet-quotient." ${ }^{\text {"6 }} \mathrm{He}$ also stated that IQ is only an estimate of the speed of intelligence development and that the Uppsala school readiness test itself was only an estimate of development as it pertained to certain aspects of the child. ${ }^{47}$

It is, however, also noteworthy that this rising level of criticism had neither stopped the practice of IQ testing within, nor undermined its influence and impact on, the Danish educational field. This aspect is most clearly visible in the channelling of efforts into creating the Danish Educational Research Institute (Danmarks Poedagogiske Institut) on February 1, 1955, which took on an iconic status in terms of test development, being the goal that the Danish educational psychologists' community had so long striven to achieve. ${ }^{48}$ Despite this achievement, ideas regarding heredity and eugenics so evident in the inter-war years were pushed into the background in favour of a growing focus and awareness regarding the role and importance of the environment in IQ testing practices. In terms of the emerging welfare state and political directions, the periods both between and after the world wars bore witness to a mounting concern with optimisation and effectiveness in education for economic growth purposes; this time, only the ideas were different.

We have sought to shed light on how the public debate reflected increasing concerns about the need to sort and exclude segments of the population viewed as problematic. In this climate, IQ testing represented a popular tool and a suitable technology to differentiate among pupils thought to have fewer mental gifts and who would therefore present challenges to the future economic success of the society. By the 1940s, educational psychologists themselves had begun to question these attitudes and opinions, calling for the need to include environmental factors in pupil assessments.

\section{Danish educational psychologists' struggle for acceptance: A new professi- on gains its footing}

In understanding the background, development, and influence of how to differentiate among students that resulted in the relations that came to prevail among IQ testing itself, the professionals who defined the tests, and the welfare state that promulgated their use, the rise of educational psychology as a profession was a critical factor.

A brief look at the Danish urban educational system, overall, in the 1920 s and 1930s reveals, in every respect, a hierarchically ordered school system at the compulsory level. At the top was the middle school for the gifted children, followed by the normal school for the moderately gifted. Next was the remedial school for those children deemed below average and, finally, the Danish national mental care institution schools for the retarded children. ${ }^{49}$ It was thus in the field of tension existing between the normal school and the remedial school that educational psychology made its entrance. The remedial school system functioned as both entry point and subsequent raison d'être of educational psychology in Denmark.

\footnotetext{
46 Marckmann (1966).

47 Ibid., 323.

48 Helge Jensen, "Udvalget for skolepsykologiske undersøgelser ekstraordinært repræsentantskabsmøde," Københavns kommuneskole 6 (1954, February 11), 90-91, 90.

49 Ydesen (2011), 57.
} 
The road to a broad acceptance of educational psychology, however, was paved with obstacles, with early educational psychologists working to ensure their position would be indispensable to the educational system. They argued that the prerequisite for successful IQ tests was based on a qualified individual administering them, someone with psychological insight and training in the use of such tests. ${ }^{50}$ IQ testing was vital to the professionalisation process, bringing to bear many useful qualities: the test demanded a certain level of technical literacy, it required specialised knowledge, and its dissemination was strictly delimited. Intelligence testing thus became the educational psychologist's professional brand.

Despite their efforts at creating professional boundaries, however, educational psychologists never did succeed in gaining a complete monopoly over intelligence testing. Medical doctors retained their right to conduct intelligence tests as well, undoubtedly due to doctors' employment in the mental care institutions in which the use of intelligence tests was widespread. Educational psychologists believed their position of authority was usurped by doctors, who were also allowed to administer intelligence tests but who themselves had completed no formal training in the intelligence testing process. ${ }^{51}$ Fundamental professionalisation issues were at stake between these two groups, forcibly joined by this mutual right to administer the tests, which created a shared knowledge monopoly. This uneasy alliance would subsequently cause problems with the school systems' reception of the emerging psychology profession, which would undermine educational psychologists' ambitious bid to fully integrate their practice into the educational system.

It is well documented how many local teachers often met the new, incoming educational psychologists with a certain resistance and scepticism, ${ }^{52}$ much as experimental psychology and educational experiments had been received among teachers in Denmark in the late 1910s and early 1920s. In 1937, a teacher, Hans O. Skovrup, pointed out the differences in the results of two competing IQ tests administered to the same pupil population, one by the psychologist Sofie Rifbjerg and another by the medical doctor H. P. T. Ørum. Skovrup drily noted: "It is evident that it is not insignificant to a child whether its placement in a remedial class or a mental care institution is decided based on the system used by Miss Rifbjerg or Dr Ørum." ${ }^{53}$

Several reasons might exist for this apparently widespread critical attitude among teachers. First, many teachers viewed educational psychologists as representatives of the reform pedagogy movement advocating for a free upbringing and freedom of the child, concepts that introduced revolution into the educational system. Second, teachers were also often sceptical regarding new examinations and tests that came from the Educational Psychology Study Commission, because they feared such initiatives would encourage lockstep conformance and inhibit a teacher's own freedom and practice. Third, these initiatives drained power from the teachers, who had lost their influence in the process of determining whether a child should be transferred

50 Sofie Rifbjerg, "Intelligensprøver," in Ledetraad ved folkelig universitetsundervisning 114, 1-4, 3.

51 Harald Torpe, Intelligensforskning og intelligensprøver (Copenhagen: Schultz, 1964).

52 Svend Færgemann, "Skolepsykologisk rådgivning i Gladsaxe kommune gennem 15 år," Skolepsykologi 3 (1966), 80; Harald Torpe, "Sofie Rifbjerg og intelligensprøverne," Dansk Pæedagogisk Tidsskrift (1986), 92.

53 Hans O. Skovrup, “Tanker om Intelligensprøven,” Folkeskolen 54, no. 4 (1937), 62. 
into remedial education. These reasons made the whole enterprise of educational psychology somewhat of an unknown factor in the everyday life of the school, one that could significantly interfere with teachers' daily practice, freedom, and influence. $^{54}$

At the municipality of Frederiksberg, however, the cradle of Danish educational psychology, Henning Meyer managed to overcome this sceptical attitude among many of his teachercolleagues. The support of the organisations, the teachers' union, and the Frederiksberg leadership undoubtedly aided him in this endeavour. Moreover, educational psychology's ability to, sometimes, rid a teacher of a troublesome child in a class would often generate an attitude that could counter any negativity, and create a community of interests between teacher and educational psychologist. In 1934, when Meyer was first officially employed as an educational psychologist, head teacher Niels Eldahl, who was also the head of the Frederiksberg remedial classes, wrote: "There is every reason to welcome the new educational psychologist," continuing: "In order to appreciate the results of educational experiments, it is necessary to have children's intelligence examined," and concluding: "Intelligence testing will be a big help for the teachers." 55

Apart from technical literacy, the strictly limited dissemination of intelligence tests, and the fight for local school acceptance as another necessary step in the professionalisation process was how to establish professional requirements for educational psychologists. According to Meyer, the educational psychologist had to acquire both practical experience as a teacher and in-depth knowledge about the discipline of psychology. ${ }^{56}$ In accordance with Meyer's precepts, the educational psychologists' union in Denmark, formed in April 1945, put forth the following minimum requirements for an educational psychologist in the late 1940s: teacher education and a minimum of five years' practical experience, preferably with some special teaching assignments, but mainly in normal school classes. In addition, all independent psychologists should receive the three-year university training course; and all assistants, the one-year course. There could be no employment at an educational psychology office until the individual had completed one year of practice. ${ }^{57}$

Before these guidelines were outlined, educational psychology in Denmark had been a muddled undertaking. Up until 1940, the only formal degree in psychology was the master of arts, and an insufficient number of people had completed this time-consuming university degree. The question concerning who could qualify to practice educational psychology was thus subject to interpretation. Sometimes, local school leaders preferred applicants for educational psychology positions if the latter were familiar with a specific remedial education area and the local educational conditions. School leaders would choose these individuals rather than bringing in outsiders, even those who met the formal education requirement. ${ }^{58}$ Accordingly, a massive effort was launched to remedy the challenges that concurrently posed a threat to these professionalisation endeavours. In 1940, the Royal Danish School of

54 Ydesen (2011), 76.

55 N. Eldahl, “Danmarks første Skolepsykolog,” Folkeskolen 51, no. 12 (1934), 198.

56 Henning Meyer, “Skolepsykologen arbejder," Folkeskolen (1943), 604.

57 Jørgensen (1955), 11 f.

58 Ibid. 
Education developed the oneyear course in applied psychology with Meyer overseeing it. ${ }^{59}$ It soon became clear, however, that the one-year course was insufficient to ensure practitioners were adequately trained, and the teachers' unions called for upgraded training of educational psychologists. ${ }^{60}$ Therefore, a greater need existed for legislation and formal education in the area.

In 1944, a three-year university training course at the University of Copenhagen was established, and in February 1950, the Ministry of Education issued a circular outlining the qualification requirements for educational psychologists. Although the Ministry's circular did not call for the same rigorous qualifications that the educational psychologists' union had in Denmark, the professionalisation process was nevertheless now running rather smoothly. In part, this was due to the educational psychologists' union exerting some degree of influence over who would be accepted as a practicing psychologist in the educational field and because these educational psychologists now offered a prize the educational system had come to value: practical knowledge. ${ }^{61}$

In sum, we have offered an analysis highlighting the role of professionalisation for psychologists. In this process of professionalisation, we see that IQ testing played a decisive role, which also affected the dominance of testing and in a wider sense the question of differentiation. Being the dominant tool in these practices and processes, the Binet test, along with the general idea of intelligence as something fixed and inherited, became a subject of criticism among professionals, as reflected in the quotation from psychologist Thomas Sigsgaard in his descriptions on his revision of the test used to introduce this article.

Our analysis indicates testing played a key role in educational psychology's emergence as a new profession. A core issue was the question of the discipline's gaining professional recognition from the state, the road to which was paved with psychologists' ability to offer a tool and the technology to conduct tests to differentiate among pupils. We cannot fully appreciate the position of educational psychology, however, without understanding its interactions with child psychiatry, which is the topic of the next section of the analysis.

\section{Child psychiatry and school psychology: A collaboration}

This section analyses the influence of the emerging field of child psychiatry on the concept of intelligence and the interpretation of pupil's problems. In the 1930s and 1940s, the gaze turned upon the child was influenced by a different set of practices and ideas: IQ testing, the progressive educational interpretation of the child as unique, and a branch of child psychiatry subscribing to environmental interpretations of the child. ${ }^{62}$ This new gaze emerged due to professional collaborations occurring

59 Torben Gregersen, Carl Aage Larsen, and Harald Torpe, eds., Poedagogiske strejftog: Festskrift til Henning Meyer, Vol. 10 (Copenhagen: Gyldendals Pædagogiske Bibliotek, 1960), ix; S. A. Tordrup, “Det skolepsykologiske arbejde i Danmark," Norsk Pedagogisk Årbok (1944), 2.

60 Jørgensen (1955), 2.

61 The passages in this section covering the post-war period are paraphrases from Ydesen's PhD dissertation, Ydesen (2011), 75-77. They have been recontextualised and updated in light of this article's focus.

62 This section primarily draws on Bjørn Hamre's ongoing research concerning the emergence and practice of educational psychiatry in Denmark. 
among teachers, educational psychologists, and psychiatrists. Educational psychologists increasingly emphasised collaboration's importance and highlighted children's psychiatric clinics as vital institutions in which useful practical knowledge could be obtained about children's mental illnesses and their possible treatment. ${ }^{63}$ Psychiatric knowledge therefore became an essential part of the professional construction of the gaze upon the deviant child. This was also the case when it came to mainstream schools' pupil sorting activities. As we have argued above, educational psychology played a decisive role in sorting pupils into remedial education classes. However, some issues, such as behavioural difficulties, needed further examination beyond what testing by educational psychologists could offer. In such cases, psychological examinations by educational psychiatrists could serve as extra-scientific legitimisation of the process of sorting children into different school tracks. As explained by one educational psychologist:

In serious cases, the educational psychologist would contact a psychiatric clinic at
which the doctors are able to do neurological and medical examinations of the child.
The educational psychologist participates in the clinical negotiations concerning tre-
atment. In some cases, the child is kept for observation; in other cases, outpatient
treatment is sufficient. ${ }^{64}$

This new type of collaboration between educational psychology and educational psychiatry led to dilemmas in terms of the professional demarcations between the two disciplines and issues of authority. This occurred when it came to establishing the first offices, where the two professions needed to collaborate, within the municipality, in examining pupils that schools considered deviant. With the establishment of educational psychiatry offices in both Aarhus and Copenhagen in the early 1940s (Aarhus, 1940; Copenhagen, 1941), psychiatry established itself as part of the process of pupil sorting. In 1940, in the municipality of Aarhus, the psychiatrist Margrethe Lomholt became head of the educational psychiatry office. In the municipality of Copenhagen, another psychiatrist, Karen Margrethe Simonsen, became educational psychiatrist, in connection with the office of the educational psychologist, but employed under the chief school doctor in the municipality. It is worth noting that as educational psychiatrist, Simonsen did not report to the head of the educational psychologist's office, but instead served under the leading educational doctor of the municipality. This separation between psychology and psychiatry served to maintain separation within the organisational structure, which may have supported controversies between the professions. As the educational psychiatrist in Copenhagen during the early 1940s, Simonsen thought that the psychologist's office referred too few pupils for psychiatric examination. In an internal report, she claimed that more pupils would benefit from a psychiatric examination, an internal criticism of the educational psychologist's practice.

Margrethe Lomholt and Karen Simonsen were, by virtue of their functions as educational psychiatrists and avid debaters in contemporary educational journals, key players and pioneers, not only in constructing this collaboration between psychology and psychiatry in relation to the deviant child, but also in their support of an envi-

63 See, e.g., H. J. Nielsen, “Skolepsykologens arbejde," Unge Podagoger (1941), 13-14.

64 Harald Torpe, “Skolepsykologens arbejde," Unge Poedagoger 8, no. 3 (1942), 85. 
ronmental interpretation as a potential source of pupil difficulties. By the beginning of the 1940s, the idea of the child as degenerate, as argued by the Danish physician August Wimmer early in the century, ${ }^{65}$ had lost its dominant position in the shaping of the new child psychiatry.

During the 1930s and 1940s, Lomholt and Simonsen, along with other Danish child psychiatrists, had introduced a new gaze upon the child, one that integrated psychoanalytic and psychological perceptions of the child's early years and that accorded greater significance to an interpretative approach. Whereas educational psychology in its formative stage drew on various testing methodologies, the practice of educational psychiatry in the 1940s was characterised by a social and interpretative approach to the deviant child. These new conceptions of young people were congruent with the progressive educational ideas that influenced schooling during the inter-war period in Denmark. ${ }^{66} \mathrm{New}$ methods of interpreting the concept of the deviant child accompanied an emerging idea of the benefit derived from interdisciplinary collaboration, as expressed by child psychiatrists. This interdisciplinary collaboration should also be understood in light of the definition of child psychiatry. In the above-mentioned article, "Børnepsychiatriske problemer i skolen" (Child psychiatric problems in schooling), Simonsen delivered a definition of child psychiatry:

What is child psychiatry? It is the study, prevention, and treatment of psychic and
nervous disturbances while [a child is] growing, in other words, the psychopathology
of childhood. Child psychiatry is a very new field, in the process of defining itself as
a unit, a demarcation that [must be done to distinguish it from other] fields. This is
because child psychiatry has grown out of many different fields - pediatrics, psychi-
atry, neurology, psychology, pedagogy, and sociology. Even though child psychiatry is
a new field, this does not mean that its problems are new; on the contrary, they have
more or less always existed, affected by the different periods of life and conditions of li-
ving. These problems to some extent have already been considered, within each of the
disciplines in which they have emerged, but without the collaboration between these
disciplines, which is precisely what is important and what is new in child psychiatry. ${ }^{67}$

What interests us about this definition is that, by the beginning of the 1940s, child psychiatry, in its scope, was linked to such diverse fields as pedagogy and sociology. This relation underscores, from the outset, the impression of child psychiatry as a distinct field in Denmark, one that sought to include more environmental interpretations in assessing children's various difficulties, for example, by taking into consideration the home and the parents' habits. Another point worth emphasising is that as child psychiatry worked to define itself, it related that definition to the collaboration it enjoyed with other allied disciplines.

Throughout the 1940s, Simonsen and Lomholt argued for this collaboration among schools, as well as between the disciplines of educational psychiatry and educational psychology. Simonsen published a pamphlet in 1943 discussing collabo-

65 Jesper Vaczy Kragh, Stine Grønbæk Jensen, and Jacob Knage Rasmussen, På kanten af velfoerdsstaten: Anbragte og indlagte i dansk socialforsorg, 1933-1980 (Odense: Syddansk Universitetsforlag, 2015), 90.

66 Ellen Nørgaard, Tugt og dannelse: Tre historier fra kulturkampens ara (Copenhagen: Gyldendal, 2005).

67 Karen Margrethe Simonsen “Børnepsychiatriske problemer i skolen,” Vor Ungdom (1942), 102. 
ration between the school and child psychiatry. In the previously cited article, "Børnepsychiatriske problemer i skolen" (Child psychiatric problems in schooling), she advocated for teachers, psychologists, and psychiatrists to collaborate, and not least, turned her attention to the pupil's home:

What is important [is] to provide children [with] the best possible conditions for a healthy and natural development so that they, in the future, are equipped to fill out their positions. This is what child psychiatry is working for. However, child psychiatry can do nothing without real cooperation from everyone concerned with children, primarily home and school, a cooperation that is so much more natural, as we all of course have the same aim: healthy, strong, and happy youth. ${ }^{68}$

This idea of collaboration thus is closely aligned with a certain group of professionals that includes everyone engaged in the future of youth. Prevention is viewed as an important ingredient in securing for the child participation in society. A new professional narrative expressed by child psychiatry had emerged, which drew on medical as well as psychological understandings, making collaboration with other professions a necessity. By the late 1940s, educational psychology was an established institution in Denmark's main cities, whereas educational psychiatry was still in a process of clarification, and part of that clarification was in establishing an interdisciplinary collaboration between the two disciplines as professional practices. Although the knowledge, as well as the professional practice, was related when it came to assessing pupils, this collaboration was seen as potentially problematic in the view held by psychiatrists, as discussed by Margrethe Lomholt in the article "Lidt om børnepsykiatri" (Something about child psychiatry):

Based on the assumption that the work of the educational psychologist and the educational psychiatrist are largely intertwined, in fact often the same, I think, and indeed I have experienced that both [professions] can benefit from the collaboration. The child psychiatrist must admit that children can be examined and treated fully satisfactorily at an educational psychologist's office, even from a child psychiatrist's perspective. This [examination] can be done, by educational psychologists with the theoretical and clinical training in psychology, excluding some cases [of children], as mentioned above, that always need to be referred to a psychiatrist. On the other hand, the educational psychologist needs to be aware that the educational psychiatrist who through the years has worked with schoolchildren's problems will become much more useful in the work, if [he/she is] not in principle excluded from the cases, which are said to be first and foremost of an educational psychological nature. ${ }^{69}$

This quotation strongly suggests that collaboration would eventually sow seeds of conflict. Whereas the field of practice is commonly concerned with examining the child, it is clear from Lomholt's words that the two types of practitioners each held strong opinions concerning how to approach their examination of pupils-and which of them was best prepared to do so. In the municipality of Copenhagen, the educational psychologist decided which children needed a further psychiatric examination, and as we have seen above in the case of Karen Margrethe Simonsen, the psychiatrist did not always agree with this assessment.

68 Ibid., 114.

69 Margrete Lomholt, “Lidt om børnepsykiatri.” Unge Pæedagoger Jubiloumsnummer (1950), 60. 
In 1948, the first Danish textbook on child psychiatry was published, Børnepsykiatri (Child psychiatry), by Margrethe Lomholt. It included her own psychological experiences of collaborating with schools in Aarhus and thus was related to pedagogical considerations. As a professional discipline, child psychiatry increasingly included achievements by international psychology. In 1950, Lomholt emphasised developments such as "the new dynamic depth psychology-oriented psychiatry, which provided the impetus for the emergence of a particular child psychiatry." ${ }^{70}$ This newdepth psychology took inspiration from psychoanalysis in the shaping of the new child psychiatry field. These developments within psychiatry may also have nurtured the emergence of the environmental view upon children's difficulties. By 1953, child psychiatry had become a medical specialisation at the University of Copenhagen.

Our analysis has illuminated how educational psychiatry may have contributed to defining educational psychology as a profession, as well as demonstrating a general movement towards applying environmental explanations in interpreting deviancy. The inter-professional collaboration was thus also part of the context of early IQ testing, and this, as well as other collaborations, is an important part of understanding the shift towards more environmental explanations, which again was important in terms of student differentiation. As expressed in the beginning of our article, this interpretation may well have been influenced by a deeper understanding of social inequalities in the emerging welfare state.

\section{Conclusion}

To understand the background, development, and influence of differentiation associated with IQ testing in Denmark between the 1930s and 1960s in the early Danish welfare state, we shall now consider several factors in light of the three related sections of analysis presented above, but will expand these perspectives by also drawing on other research.

In general, various factors influenced IQ testing's development as a practice in the Danish educational system during this period. The political context of the emerging Danish welfare state, as shown in the public debate, forwarded the need for technologies as a means to differentiate among members of the population. This is partly seen in the wish of cultivating the intelligence pool, and partly in the legislation of the period that aimed to exclude part of the population, for example, those seen as feebleminded and therefore less productive. However, as underscored in the analysis, the eugenicist viewpoint was questioned as educational psychologists gained greater influence, and absorbing new interpretations on the question of giftedness began to pay more attention to environmental and social factors.

As demonstrated in the second and third parts of our above analysis, the professionalisation of educational psychologists, the inter-professional collaboration with child psychiatrists, and influences from the fields of child psychology, psychoanalysis, and progressivism brought forth new ideas that challenged the eugenicist ideas of intelligence and giftedness, and instead paid attention to childhood conditions and the impact of sociological factors. Such ideas corresponded, supported, and aligned with the ideals of equality of the emerging welfare state. These factors included the 
increasing professionalisation of the educational system, entailing a rise in the division of labour among professional groups, as well as debates among professionals that reflected different ideas about eugenics, heredity, and social equality.

We have argued that recurring political concerns in terms of education were those of effectiveness and optimisation for the sake of economic growth. Themes such as intelligence and mental development were central within prevailing psychological theories. Psychology was an evolving academic field internationally as well as in Denmark. For these reasons, questions of how to "assess" intelligence certainly must have appeared valuable to certain dominant psychologists of the period, who also maintained a general interest in psychometrics. Psychology, as an academic field, was struggling to gain acceptance as a science, which meant that positivism-and with it, attempts to produce knowledge based on controlled experiments and testsgained currency. Such tendencies seemed to match well with initiatives focussing on the design of intelligence tests.

Educational psychologists successfully secured responsibility for streaming children. To do so effectively, however, they needed tools to aid in diagnosing any deficiencies and reach psychological conclusions. These working professionals would no doubt regard intelligence tests as highly useful—both to use in carrying out their own responsibilities as well as in establishing their profession as viable, since they would only have to share their monopoly in using such tests with doctors and psychiatrists. Accordingly, the testing process would impart their psychological decisions with a gloss of scientific imprimatur.

However, as appeared from the analysis of the public debates and also mentioned above, an increased attention on the question of how to handle and conduct such differentiation between individuals in the emerging welfare state and a steadily growing public educational system emerged. Intelligence testing appeared as a technology that could produce such differentiation in a manner perceived as professional, which could legitimise decisions concerning questions of, for example, how to sort pupils into different kinds and levels of schooling. Thus, IQ testing gained a strong foothold within the different professional contexts. At the same time, the public debates that took place among members of these professional contexts reflected an increasing interest in and attention to the problems of different conceptualisations of intelligence as reflected in the nature-nurture debates. Prominent psychologists raised critiques of the belief that an individual's IQ was inherited and fixed, instead arguing for it as more of a social and cultural construct. Therefore, a field of tension characterised by strong contradictions and opposing interests was formed in this context. On the one hand, such technology was needed by the society and was adapted by certain professionals-in fact, was also employed in forming their given professions. On the other hand, the professionals themselves recognised and acknowledged the inherent problems of such a practice.

As discussed by Ball in his historical analysis of the English educational system, establishing educational policy takes place through a continual reconstruction of the relationship between normality and deviation. ${ }^{71}$ This relationship gains scientific legitimacy through its alliance with psychology and psychiatry, the disciplines Nikolas Rose calls the "psy-sciences" that enable and legitimise various categorisations, and 
therapeutic and educational interventions. ${ }^{72}$ Our analysis in this article concerning the increasing importance of environmental explanations in testing pupils' intelligence exemplifies the shifting nature of the relationship between considerations of normality and deviance. Ball moves the analysis a step further when he includes Foucault's reflections on how mechanisms of discipline and security interact when the role of the educational system in the welfare society is analysed..$^{73}$ In turn, these insights may help us move further along the path toward understanding the role of IQ testing in the emerging Danish welfare state.

Mechanisms of discipline reflect societal efforts to organise and sort; therefore, leaders might separate individuals whose behavioural patterns are viewed as desirable from those who display undesirable patterns. The key function of discipline works to calibrate certain norms (norming) in encouraging desirable behaviour in schools. In other words, the testing practice of educational psychology may be viewed as an effort to standardise different degrees of intelligence and separate children accordingly. These practices for norming occur via numerous tools used to categorise normality and deviancy; psy-sciences such as psychology and psychiatry deliver scientifically based distinctions between the normal and the deviant. Constructing intelligence as something innate and fixed may appear to promote elitism concerning testing's role in education, particularly when such tests are applied in school settings with pupils sorted into different classes based on their test scores. It can be considered an execution of power when an IQ test score serves to limit future opportunities for success by narrowing the choice to a question of whether a pupil was born with the right genes. Mechanisms of discipline, as sketched out by Foucault and Ball, therefore might explain how a fixed notion of intelligence could benefit the stabilisation of societal inequities.

According to Foucault and Ball, an analysis of these mechanisms of discipline should be supplemented by corresponding analysis that examines how mechanisms of security affect the ways in which a welfare society relates to deviation and deviant behaviour. ${ }^{74}$ Unlike disciplinary mechanisms that set standards, security mechanisms seek to normalise through examinations and sanctions, working to prevent the unexpected from happening. According to Foucault, the bell curve serves as example of an explanation that modern societies offer concerning normalising the distribution in the population's intelligence. ${ }^{75}$ This curve reflects an intention, along with other security mechanisms, to respond to unforeseen events, and to serve as a tool for performing analyses and assessments to minimise the presence of certain risks within society.

The change in society's conception and understanding of intelligence that brought with it added environmental explanations may reflect the emerging welfare society's security mechanisms. These mechanisms were intended to accommodate the presence of unpredictable circumstances and events that could affect children's behaviour and upbringing, factors that could not be encompassed by a notion of intelligence as something innate and fixed. Therefore, the environmental turn in the Danish notion

\footnotetext{
72 Rose (1998).

73 Ball (2013); Foucault (2009).

74 Ibid.

75 Foucault (2009).
} 
of intelligence testing may be a reflection of such security mechanisms in the emerging welfare society. The growing influence of child psychiatry and the institutionalisation of educational psychiatry in the gaze upon the child both point to the flexible functions of the security mechanisms, the locus at which the third part of our analysis applies. Drawing on the analysis of security in the welfare state-as sketched out by Foucault's analysis and in line with Ball's analysis of the educational system-the institutionalisation of educational psychiatry reflects a necessary change in security technology that can be applied to sorting students in the school setting. Handling diversity in the schooling system was not only a matter of having the right technologies for intelligence testing, but also became ever more related to the new environmental gaze turned upon the child. In this process, psychiatry, the related influence of psychoanalysis, and a rising social understanding concerning children's problems all brought forth new explanations of diversity and managed to deliver new tools for sorting that drew on the environmental gaze directed toward children's development as well as their problems. The newly established collaboration between educational psychology and psychiatry is an example of a more advanced method of coping with diversity. In analysing the function of equality and inequality in society, the environmental turn played a significant role in the differentiation of pupils in the Danish schooling system. The environmental turn made it possible to adapt to increasing levels of variation observed in pupils' capabilities and their social backgrounds, as well as in the growing influence of new psychiatric practices employed in examining young people. As such, the environmental turn may even reflect a willingness to cope with and address social inequality in an evolving and supposedly universalistic Danish welfare state.

With equality being one of its core tenets and the guiding principle of the emergence of a welfare provision, the state found, and still finds, itself confronted with a dilemma in the field of tension that exists between treating citizens as individuals and thus in different ways while recognising and realising ideas of equality. Such questions of differentiation needed to be addressed and treated in the emerging welfare state amid its complex and steadily growing population. Considered in its historical perspective, a tool such as IQ testing was seen as an effective and suitable technology that was embraced and adapted by the state and employed by various professionals.

Obviously such a technology, and the practices of which it was part, played a key role in how differentiation was actually conducted, in how individuals were being sorted into, for example, different kinds of schooling offered by the welfare state. It might be concluded that mental testing has played a profound role in forming the social structures of the Danish welfare state. 


\section{References}

Axelsson, Thom. Rätt elev i rätt klass: Skola, begåvning och styrning, 1910-1950. Linköping: Linköpings universitet, 2007.

Bakker, Nelleke. "A Culture of Knowledge Production: Testing and Observation of Dutch Children with Learning and Behavioural Problems (1949-1985)." Paedagogica Historica 53, nos. 1-2 (2017), 7-23.

Ball, Stephen J. Foucault, Power, and Education. New York: Routledge, 2013.

Banke, Cecilie F. Den sociale ingeniørkunst i Danmark: Familie, stat og politik fra 1900 til 1945. Roskilde: Roskilde Universitetscenter, 1999.

Becker, Kirk A. "History of the Stanford-Binet Intelligence Scales: Content and Psychometrics." In Stanford-Binet Intelligence Scales. 5th ed. Assessment Service Bulletin, no. 1, 2003. Itasca, IL: Riverside Publishing.

Bendixen, Carsten. Psykologiske teorier om intelligens og folkeskolens elevdifferentiering: En analyse af transformationen af psykologiske teorier om intelligens som baggrund for skole-psykologiske og poedagogiske afgørelser vedrørende elevdifferentiering $i$ det 20. århundredes folkeskole. Roskilde: Forskerskolen i Livslang Læring, Roskilde Universitetscenter, 2006.

Buchardt, Mette, Pirjo Markkola, and Heli Valtonen. "Education and the Making of the Nordic Welfare States." In Education, State, and Citizenship: A Perspective in the Nordic Welfare State History, edited by Mette Buchardt, Pirjo Markkola, and Heli Valtonen, Helsinki: NordWel Studies in Historical Welfare State Research, 2013.

Carson, John. The Measure of Merit: Talents, Intelligence, and Inequality in the French and American Republics. Princeton: Princeton University, 2007.

Carson, John. "Mental Testing in the Early Twentieth Century: Internationalizing the Mental Testing Story." History of Psychology 17, no. 3 (2014), 249-255.

Chapman, Paul D. Schools as Sorters: Lewis M. Terman, Applied Psychology, and the Intelligence Testing Movement, 1890-1930. New York and London: New York University Press, 1988.

"Cirkulære af 26 Juni 1943 vedrørende gennemførelse af særundervisning for børn, der ikke kan følge den almindelige undervisning." Folkeskolen (1943), 525.

Danish Ministry of Education. Betcenkning afgivet af det af UVM nedsatte udvalg vedrørende oprettelse af scerklasser i folkeskolen for børn, der ikke kan følge den almindelige undervisning. Copenhagen: Danish Ministry of Education, 1943.

de Coninck-Smith, Ning, Charlotte Appel, Morten Fink-Jensen, Christian Larsen, Erik Nørr, Pernille Sonne, Anette Faye Jakobsen, Christian Ydesen, and Lisa Rosén Rasmussen, eds. Dansk skolehistorie: Hverdag, vilkår og visioner gennem 500 år. Volume IV. Aarhus: Aarhus universitetsforlag, 2013.

Eldahl, N. "Danmarks første Skolepsykolog.” Folkeskolen 51, no. 12 (1934), 198.

Esping-Andersen, Gøsta. The Three Worlds of Welfare Capitalism. Princeton: Princeton University Press, 1990.

Færgemann, Svend. "Skolepsykologisk rådgivning i Gladsaxe kommune gennem 15 år." Skolepsykologi 3 (1966), 80-87.

Foucault, Michel. "The Confession of the Flesh.” In Power/Knowledge: Selected Interviews and Other Writings (1972-1977), edited by Colin Gordon, 194-228. London and New York: Pantheon Books, 1980.

Foucault, Michel. Security, Territory, Population: Lectures at the Collège de France, 1977-78. New York: Palgrave Macmillan, 2009. 
Goodey, Christopher F. A History of Intelligence and "Intellectual Disability:" The Shaping of Psychology in Early Modern Europe. Farnham, Surrey and Burlington: Ashgate, 2011.

Gould, Stephen J. The Mismeasure of Man. New York: W. W. Norton, 2008.

Gregersen, Torben, Carl Aage Larsen, and Harald Torpe, eds. Poedagogiske strejftog: Festskrift til Henning Meyer (Vol. 10). Copenhagen: Gyldendals Pædagogiske Bibliotek, 1960.

Haas, Peter M. "Epistemic Communities and International Policy Coordination." Int. Org. 46 (1992), 1-35.

Hamre, Bjørn. Potentialitet og optimering i skolen: Problemforståelser og forskelsscetninger af elever. Copenhagen: Aarhus University, 2012.

Hamre, Bjørn and Christian Ydesen. "The Ascent of Educational Psychology in Denmark in the Interwar Years." Nordic Journal of Educational History 1, no. 2 (2014), 87-111.

Hearnshaw, Leslie S. The Shaping of Modern Psychology. London and New York: Routledge \& Kegan Paul, 1987.

Ingbøl, Kaj. "Den rettidige forsorg for lettere aandssvage.” Folkeskolen (1937), 187.

Jacó-Vilela, Ana Maria. "Psychological Measurement in Brazil in the 1920s and 1930s." History of Psychology 17, no. 3 (2014), 237-48.

Jensen, Ejvind, and Wilhelm Marckmann. "En prøve for skolebegyndere." Dansk Poedagogisk Tidsskrift 3, (1955), 161-168.

Jensen, Helge. "Udvalget for skolepsykologiske undersøgelser ekstraordinært repræsentantskabsmøde.” Københavns kommuneskole 6 (1954, Feb. 11), 90-91.

Jørgensen, Ingvard Skov. Det skolepsykologiske arbejde i Danmark. Copenhagen: Skolepsykologisk forlag, 1955.

Juul, Ida. "Den danske velfærdsstat og uddannelsespolitikken." Uddannelseshistorie 40 (2006), 72-100.

Kaalund-Jørgensen, Frederik Christian. "Hvad gør vi for de Børn, der ikke kan følge Folkeskolens almindelige Undervisning?” Hjälpskolan (1942), 87-95.

Kirkebæk, Birgit. Abnormbegrebet i Danmark i 20'erne og 30'erne med sarlig henblik på eugeniske bestrobelser - og iscer i forhold til åndssvage. Copenhagen: Danmarks Lærerhøjskole, 1985.

Kirkebæk, Birgit. Da de åndssvage blev farlige. Holte: SOCPOL, 1993.

Kirkebæk, Birgit. Uduelig og ubrugelig: Andssvageanstalten Karens Minde, 18801987. Holte: SOCPOL, 2007.

Koch, Lene. Racehygiejne i Danmark, 1920-56. Copenhagen: Gyldendal, 2000.

Kragh, Jesper Vaczy, Stine Grønbæk Jensen, and Jacob Knage Rasmussen. På kanten af velfordsstaten: Anbragte og indlagte i dansk socialforsorg, 1933-1980. Odense: Syddansk Universitetsforlag, 2015.

Leopoldoff, Irina. "A Psychology for Pedagogy: Intelligence Testing in the USSR in the 1920s." History of Psychology 17, no. 3 (2014), 187-205.

Lomholt, Margrete. "Lidt om børnepsykiatri." Unge Podagoger Jubiloumsnummer (1950), 58-60.

Marckmann, Wilhelm. "Nogle erfaringer fra brug af Uppsalaprøven." Dansk Poedagogisk Tidsskrift 14, (1966), 316-332.

McNutt, Steve. "A Dangerous Man: Lewis Terman and George Stoddard, Their Debates on Intelligence Testing, and the Legacy of the Iowa Child Welfare Research Station." Annals of Iowa 72 (2013), 1-30. 
Meyer, Henning. “Skolepsykologen arbejder.” Folkeskolen (1943), 603.

Meyer, Henning. "Psykologien og Skolen.” In Opdragelse og undervisning i Danmark, edited by E. Torsting (Vol. I, pp. 287-307). Copenhagen: Alfred Jørgensens forlag, 1948.

Mülberger, Annette. "The Need for Contextual Approaches to the History of Mental Testing." History of Psychology 17, no. 3 (2014), 177-186.

Nielsen, H. J. “Skolepsykologens arbejde." Unge Podagoger (1941), 5-6.

Nørgaard, Ellen. Tugt og dannelse: Tre historier fra kulturkampens ara. Copenhagen: Gyldendal, 2005.

Ploug, Niels, Ingrid Henriksen, and Niels Kærgård. Den danske velfoerdsstats historie: Antologi. København: Socialforskningsinstituttet, 2004.

Reese, William J. Testing Wars in the Public Schools: A Forgotten History. Cambridge: Harvard University Press, 2013.

Rifbjerg, Sofie. Hjolpeskolebørn. 2d ed. Copenhagen: Gyldendals Pædagogiske Bibliotek, 1963.

Rifbjerg, Sofie. "Intelligensprøver." Ledetraad ved folkelig universitetsundervisning 114, (1941), 1-4.

Rose, Nikolas. Inventing Our Selves: Psychology, Power, and Personhood. Cambridge: Cambridge University Press, 1998.

Samelson, Franz. "On the Science and Politics of the IQ." Social Research 42 (1975), 467-488.

Simonsen, Karen Margrethe. "Børnepsychiatriske problemer i skolen.” Vor Ungdom (1942), 101-114.

Skovrup, Hans O. “Tanker om Intelligensprøven.” Folkeskolen 54, no. 4 (1937), 6263.

Spelling, Kaj. “Skolepsykologerne og deres prøver.” In Børn, loerere, psykologer: En bog til Thomas Sigsgaard, edited by Jesper Florander and Hans Vejleskov, 102111. Copenhagen: Munksgaard, 1979.

Sufian, Sandy. "Compounded Anxieties: Adoptive Family Building and the Role of Disability in Adoption IQ Studies." Journal of the History of Childhood and Youth 7, no. 3 (2014), 398-429.

Terman, Lewis M., and Maud A. Merrill. Measuring Intelligence: A Guide to the Administration of the New Revised Stanford-Binet Tests of Intelligence. London: George G. Harrap and Company Ltd., 1937. Reprinted 1946, 1947, 1948.

Tordrup, Sofus Albin. "Det skolepsykologiske arbejde i Danmark." Norsk Pedagogisk Årbok (1944), 1-6.

Torpe, Harald. “Skolepsykologens arbejde.” Unge Poedagoger 8, no. 3 (1942), 84-87.

Torpe, Harald. Intelligensforskning og intelligensprøver. Copenhagen: Schultz, 1964.

Torpe, Harald. “Sofie Rifbjerg og intelligensprøverne." Dansk Pcedagogisk Tidsskrift (1986), 276-277.

Troldahl, J. “En Race gaar under?” Folkeskolen (1933), 803.

UNESCO. School Psychologists (Vol. 105). Geneva: UNESCO, 1948.

Wall, William Douglas, ed. Psychological Services for Schools. New York: UNESCO Institute for Education, 1956.

Ydesen, Christian. The Rise of High-Stakes Educational Testing in Denmark, 19201970. Frankfurt: Peter Lang Verlag, 2011. 